\title{
Political Consideration and Development of Economic Relations, Economic Cooperation Capacities of Iran and the Republic of Azerbaijan
}

\author{
Tavakol Lotfi \\ Department of International Law, Faculty of law, Baku State University, Baku, Azerbaijan \\ tavakollotfi@gmail.com
}

Vali Golmohammadi

Department of International Relations, Faculty of Human Science, Tarbiyat Modares University, Tehran, Iran Corresponding Author: V.golmohammadi19@gmail.com

\section{Hamid Sarmadi}

Department of political Science, faculty of Human Science, Associated at Islamic Azad University, Bonab Branch, Bonab, Iran hamedsarmadi2000@yahoo.com

\section{Doi:10.5901/mjss.2016.v7n3s3p72}

Abstract

Azerbaijan has a very central and decisive role in the Iranian politics in the Caucasus. Since the collapse of the Soviet Union and independence of Azerbaijan, relations between Tehran-Baku has usually been good with leaps and bounds during the past two decades. Factors such as having a shared history and culture and potentials for economic cooperation function as a stimulus for the development of bilateral relations. However, the relations are faced with obstacles and deterrents such as continuing disputes about the legal regime of the Caspian Sea, relations with Israel and the US and NATO accession by Azerbaijan are in place. Azerbaijani authorities also see the Islamic Republic of Iran's foreign policy towards the issue of Nagorno-Karabakh and extensive relations with Armenia as the most important obstacles to improved relations between the two countries. Therefore, despite some opportunities to improve bilateral relations between Tehran and Baku, challenging factors and restrictions have actually increased. This research provides a brief survey of the relations between Iran and Azerbaijan based on statistics of economic and trade relations, and the causes of development of economic relations and economic cooperation between Iran and Azerbaijan on the other hand, and uses descriptive and experimental method (statistical) to study capacity and balance of economic relations between the two countries given political considerations on the one hand.

Keywords: Azerbaijan, Iran, economic relations, foreign policy, cooperation capacity

\section{Introduction}

The vacuum created by the collapsing of Soviet Union in its southern regions is rapidly filling by new relations that characterized by recent geopolitical facts in the central Asia. The newly independent states and older countries in the region have begun to look at each other and to discover new neighbors. Most people have redefined that as a result of nearly two centuries of separation many things have dramatically changed. By regarding this critical point, the lifting of the iron curtain did not bring about an automatic integration.

The relations between Iran and Azerbaijan, after independence of the Republic, has seen a lot of ups and downs. During President Ayaz Mutallibov ${ }^{1}$ and with the commencement of Nagorno-Karabakh War, the Islamic Republic tried to solve the crisis through mediation. During this period, Azerbaijan showed a growing tendency towards Russia and was still in a state of confusion as a result of the Soviet Union collapse and the independence and start of Nagorno-Karabakh War. With the coming to power of the Popular Front's Abulfazl Ilchi Beig, the Republic's relations with Russia and Iran decreased and the West and Turkey became the main objective of the foreign policy of the Republic of Azerbaijan. The excesses of the People's Front movement and expedition of an army division led by Huseinov in Baku, Ilchi Beig was

${ }_{1}$ Ayaz Niyazi oglu Mutallibov (Azerbaijani: Ayaz Niyazi oğlu Mütəllibov, born 12 May, 1938, Baku) was the last leader of Soviet Azerbaijan, and the first President of independent Azerbaijan from October 1991 till May 1992. 
forced to resign and Heydar Aliyev 2 took power. In this period, Azerbaijan started moderate relations with Russia, the West and the major regional powers. This period can be considered as period of stability in the relations of Azerbaijan with Western orientation (Hunter, 1993: 245-265). Upon Heydar Aliyev's death, Ilham Aliyev was elected president. Ilham Aliyev continued past policies and tried to develop the country by spending currencies gained from energy exports. The relation between Iran and Azerbaijan has been affected by internal, regional and international factors Heydar Aliyev defined Azerbaijan's development based on the Western model, but it also welcomed development of relations with regional countries. In 1992-95, Iran was the top trade partner of the Republic. Upon exclusion of Islamic Republic of Iran from the oil project of the century, under the pressure from the US government, relations between the two countries was affected by distrust and the Islamic Republic of Iran fell from the first to the third trade partner of Azerbaijan. Turkey and Russia were serious rivals of Iran in this period (Adeebfar, 2006: 54-56).

But another factor that led the two countries to the conflicts of interests was the issue of the legal regime of the Caspian Sea. The height of the confrontation between Iran and Azerbaijan over the use of resources of the Caspian Sea occurred in 2001, so that in July 2001, Tehran threatened that in case of Baku's failure in withdrawal of oil exploration ships owned by a British company, Tehran would resort to force, and upon Baku's ignorance of the warning, Iran showed a decisive response: a Persian warship was sent to Alborz region and expelled the oil exploration ships from the region (Ghorbanpoor, 2010: 69-75).

Upon Ilham Aliyev coming to power from New Azerbaijan Party ${ }^{3}$, the turn was come to the alliance with the West more. With the removal of Iranian path from the Baku - Tbilisi - Ceyhan pipeline, Azerbaijan was considered as a country of energy supply and the South Caucasus became an arena of competition for regional and extra-regional countries (Ismailzade, 2008: 30-62).

Relations between the two countries over these years was affected by a series of values and norms and identifying internal and external factors. These physical and ideological structures have create a semantic system that have formed identity, interests and actions of Iran and Azerbaijan. It should be noted that besides political factors such as the export of low quality goods, unhealthy competition between the traders and the Iranian industry in the republic, lack of commercial institutional arrangements, lack of export credits and export of technical and engineering services, lack of proper transportation systems for the transfer of goods and bad condition of tourism and above all lack of presence of the banking system of Iran in the country are among other cases affecting the relations of the two countries. The main question is: What factors did cause the changes in the economic relations between Iran and Azerbaijan in 1995?

Tension between the two countries as a result of differences of opinion in relation to issues such as the legal regime of the Caspian Sea, the issue of ethnicity and political Islam, the tendency of the Republic of Azerbaijan to the West, a change in economic relations between the two countries has been followed(Bourtman, 2010: 54-58). In this study, a part is focused on the factors affecting economic changes of the two countries and the other on the cooperation capacities of the two countries.

\section{The theoretical framework; tension of diplomatic relations and the decline of economic exchanges}

In the context of realistic structure of the international system as well as the views of mainstream economic approaches, two basic concepts exist to explain the rise and fall of political relations between the two political units that are influenced by policymakers and decision makers and foreign policy makers of the units. Each political unit in anarchic system is deemed as a rational player, whose percentage of increase and decrease of benefit is considered in relation to other political units. Such interests and cost can be considered as economic interests, and even identity interest. However, in line with this framework, there is realistic and economical approach to distinguish (Waltz, 1979:224-256). A distinction must be made between low politics and high politics within realist and neo-liberalist economic context. Security and keeping system in an anarchic structure in the international system and regional security complex is viewed as an issue of the high politics by the foreign policy decision-makers, while economic relations are issues of High Politics(Wieclawski, 2011: 23-25).

There should be a distinction between developed countries and developing countries; because security preferences and relation other political units in the region is different for different countries. In the South Caucasus,

\footnotetext{
2 Heydar Alirza oglu Aliyev or Geidar Aliev (Azerbaijani: Heydər Olirza oğlu Oliyev, was the third President of Azerbaijan for the New Azerbaijan Party from October 1993 to October 2003, when his son Ilham Aliyev succeeded him

3 The New Azerbaijan Party (Azerbaijani: Yeni Azerbaycan PartiyasI, YAP) is the ruling political party in Azerbaijan. It was formed on 18 December 1992 by the former President of Azerbaijan Heydar Aliyev, who led it until his death in 2003. It is now led by his son, Ilham Aliyev, who succeeded his father as the party leader and as President of Azerbaijan since 2003.
} 
security issues in the relations between the Islamic Republic of Iran and Azerbaijan, there is high politics view of the security challenges by both countries, while increase of economic relations can be understandable in terms of low politics. The other point that should be consider in the face of theoretical framework is pertinent to foreign policies of political units and their considerations towards other units. In present age which characterized by globalization, the economic development and maximizing trade indicators is mainly rooted in pragmatic foreign policy and reconciliation with the neighbors (Golmohammadi and et al, 2015).

Affected by adverse political relations and directions of foreign policy of the Islamic Republic of Iran and Azerbaijan, economic relations between the two countries in the years of independence the Republic of Azerbaijan up to the year 2014 have always been subject to a lot of ups and downs. Iran in the early years of independence ranked first among trading partners and the Turkish and US officials have followed Iran in rank. Iran's exports to Azerbaijan were mainly textiles, essential oils and resins like and shoes and most of Iran's imports from Azerbaijan were fuel and iron (Herzik, 2006: 40).

An oil exploration company was found jointly between Iran, Russia and Azerbaijan to find oil in the Caspian Sea. In the same year, under a contract, Iran and Azerbaijan agreed to start joint drilling in the Caspian Sea (Mojtahedzade, 2000). Economic relations between the two countries in the years of independence of Azerbaijan up to 2008 have been subject to many ups and downs. In 1992, Iran's exports to Azerbaijan valued \$ 27 million and imports from the country amounted to \$ 199 million, more than 80 percent of Iran's imports were petroleum products (World Bank Group, 2008).

In 1993, Iran's exports to the Republic of Azerbaijan reached 66 million dollars and imports from that country reached \$ 409 million and total exchanges increased from 266 to 475 million dollars. In 1994, Iran's exports reached \$ 197 million and imports from that country increased by 392 million dollars and total exchanges reached \$ 9589 million. In 1993 and 1995, trade between the two countries was in a golden period. Since 1995, with the expulsion of Iran from Azerbaijani oil consortium and other hostile actions, relations between the two countries deteriorated (Ibid, 2008).

Economic relations between the two countries has been declining since 1995. In this period, we saw changes in economic relations between the two countries. In 1995, Iran's exports to Azerbaijan reduced from \$ 719 million in the last year to \$ 361 million and imports of the country fell from 392 to 209 million dollars and total trading fell from 589 million dollar to 273 million dollars. In 1996, turnover increased slightly to 440 million dollars, but in 1997, upon reduced purchase of gasoline by Iranian from Azerbaijan, turnover fell to 212 million dollars and in 1998 it fell to 159 million, and in 1999, it decreased to 145 million dollars. Over the years, Iran's position in the foreign trade of Azerbaijan changed from the first place to fifth and then eighth place (World Bank Group, 2008). This change is shown in the following graph:

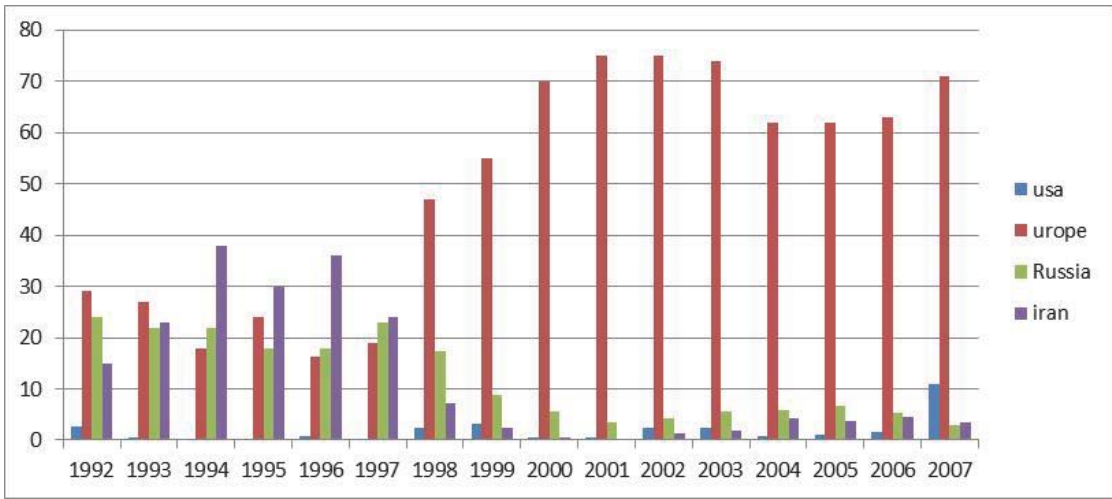

Chart (1): Fluctuation of Iran-Azerbaijan Economic Relations

Source: the World Bank Group: Azerbaijan indexes, 2008.

By 2008, the country ranked fourth among trade partners of Azerbaijan and as to the top 10 trade partners of Azerbaijan, Iran had no place. 


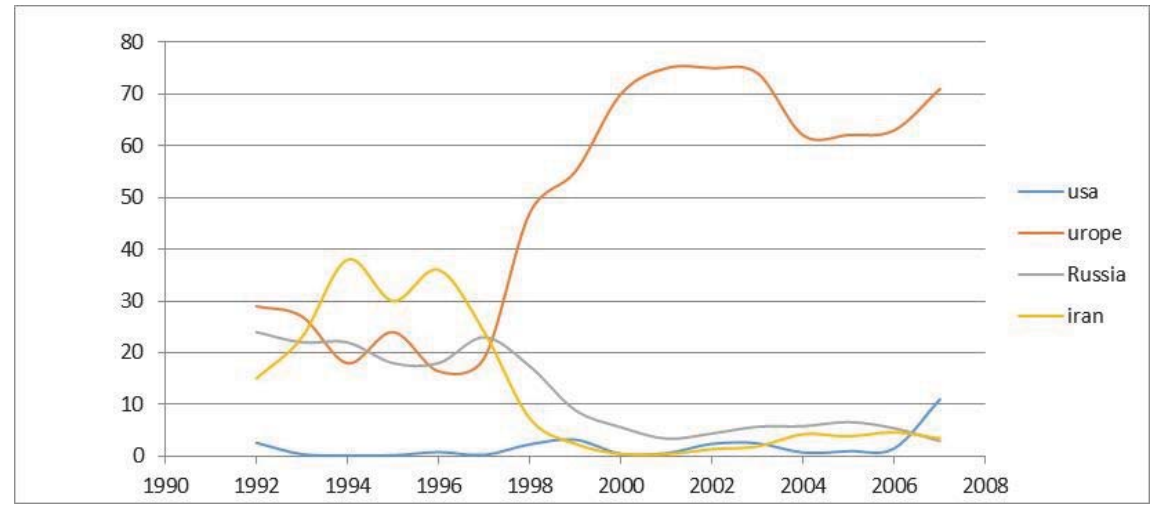

Chart (2): Minimizing of Iran-Azerbaijan Economic Relations

Source: the World Bank Group: Azerbaijan indexes, 2008.

The situation today (2014) is maintained. This reflects the fact that since 1955, the bilateral relations of mutual trust as regards the security and economic relations have declined.

\section{The economic situation in Azerbaijan; Features and indexes}

Azerbaijan's high economic growth has been attributable to large and growing oil and gas exports, but some non-export sectors also featured double-digit growth, including construction, banking, and real estate. Oil exports through the BakuTbilisi-Ceyhan Pipeline, the Baku-Novorossiysk, and the Baku-Supsa pipelines ${ }^{4}$ remain the main economic driver, but efforts to boost Azerbaijan's gas production are underway. The eventual completion of the geopolitically important Southern Gas Corridor between Azerbaijan and Europe will open up another, albeit, smaller source of revenue from gas exports. Azerbaijan has made only limited progress on instituting market-based economic reforms. Pervasive public and private sector corruption and structural economic inefficiencies remain a drag on long-term growth, particularly in nonenergy sectors. Several other obstacles impede Azerbaijan's economic progress, including the need for stepped up foreign investment in the non-energy sector and the continuing conflict with Armenia over the Nagorno-Karabakh region. Trade with Russia and the other former Soviet republics is declining in importance, while trade is building with Turkey and the nations of Europe. Long-term prospects depend on world oil prices, Azerbaijan's ability to negotiate export routes for its growing gas production, and its ability to use its energy wealth to promote growth and spur employment in non-energy sectors of the economy (Azerbaijan Economy Profile, 2014).

Among the republics of the Soviet Union, the Republic of Azerbaijan has a special place with regard to energy and mineral resources. Collapse of integrated economy of the Union linked to the Nagorno-Karabakh war problems. The effects of these difficulties was seen not only in the energy sector but also in agriculture and services. The main export of the country is oil. The most important production in this sector is carried out by Western companies and BP is one of the most important companies. Azerbaijan' problem to produce and export oil lies in time-dependent structures of the Soviet Union and to improve the situation, there is need for new investment. Baku-Ceyhan pipeline is among such investments, which transfers Azerbaijani oil to Ceyhan on the Mediterranean coast. Iran and Azerbaijan have great economic potentials for cooperation. The table below shows the gross domestic product and general economic indexes of Azerbaijan.

4 The Baku-Supsa Pipeline (also known as the Western Route Export Pipeline and Western Early Oil Pipeline) is an 833-kilometre (518 mi) long oil pipeline, which runs from the Sangachal Terminal near Baku to the Supsa terminal in Georgia. It transports oil from the AzeriChirag-Guneshli field. 


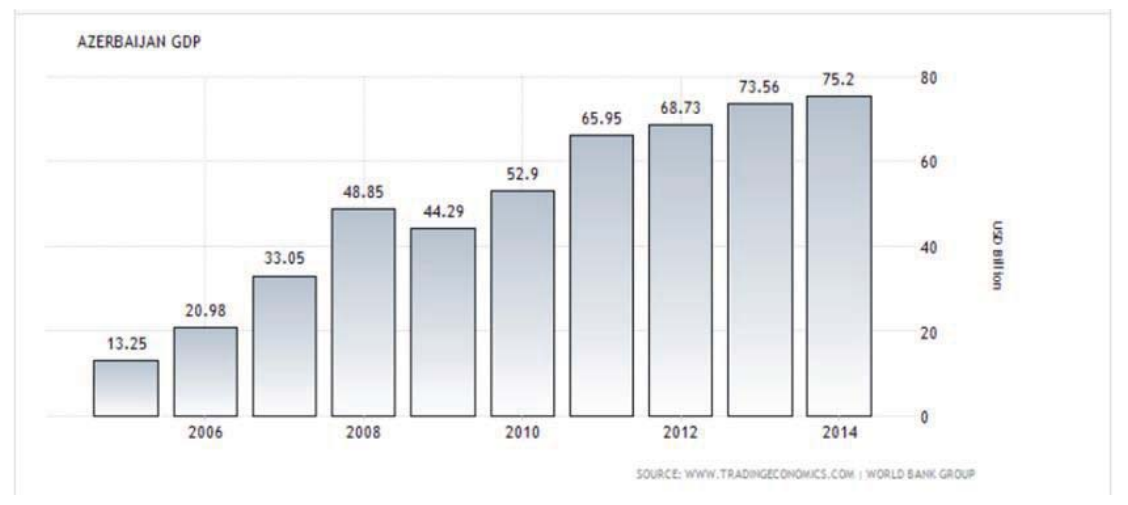

Chart (3): Gross domestic product of Azerbaijan (2002-2014)

Source: trade economics; World Bank Groups (2014)

Table (1): Azerbaijan economic indicator(2015)

\begin{tabular}{|l|r|r|r|r|}
\hline Selected economic indicators (\%) & \multicolumn{2}{|c|}{2015} & \multicolumn{2}{|c|}{2016} \\
\hline & ADO 2015 & Update & ADO 2015 & Update \\
\hline GDP Growth & 3.0 & 3.0 & 2.8 & 2.8 \\
\hline Inflation & 6.0 & 6.0 & 5.5 & 5.5 \\
\hline Current Account Balance (share of GDP) & 12.0 & 6.0 & 13.4 & 8.0 \\
\hline
\end{tabular}

Source: Asian Development Outlook 2015

Growth accelerated to $5.8 \%$ from $2.2 \%$ in 2012 , driven mainly by a $10 \%$ expansion in the $52 \%$ of the economy not directly connected with oil. Fiscal policy in Azerbaijan is driven largely by oil income, which accumulates in the State Oil Fund of Azerbaijan (SOFAZ), from which transfers are made to finance budget expenditures. Transfers from SOFAZ provide about $58 \%$ of total revenues. Improved tax administration contributed to tax revenues exceeding expectations. Generally, it could be mentioned that the main Azerbaijan export destination is restricted to the central Asia and some European countries in which its import is considerably lower than its export due to oil exportation.

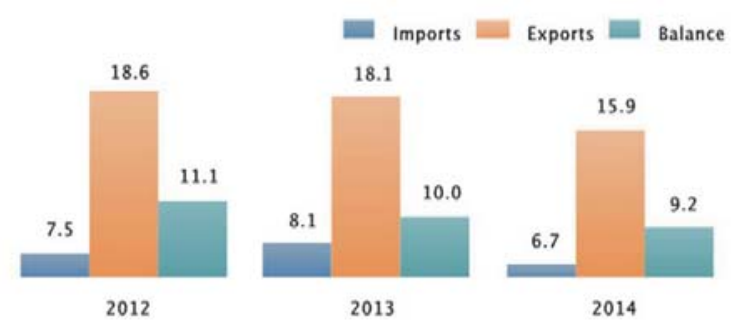

Chart (4): Trade indicators of Azerbaijan (billions of Euros)

Source: IMF (direction of trade statistics-2014)

Foreign investment in the non-energy sector, continued Karabakh conflict and its negative impact on the economy of Azerbaijan, trade with CIS countries and Russia, as well as Turkey and Europe are the issues that the country tries to manage the renovation and reconstruction of its economy. $41 \%$ of the labor force are in the agricultural sector and $7 \%$ in the industrial sector are working. 52 percent are in the service sector. Unemployment rate is $1.1 \%$. The national currency 
is manat. The government replaced since January 2006 the new manat that is equal to five thousand old mantas. To the Government of the Republic of Azerbaijan, exploitation of oil and gas reserves according to world prices provides a clear perspective. Attracting foreign investment for development goals is a key instrument and Azerbaijan's leadership has organized much efforts in this area.

Table (2): FDI indexes of Azerbaijan (2014)

\begin{tabular}{|c|c|c|c|}
\hline Foreign Direct Investnent & 2012 & 2013 & 2014 \\
\hline FDI Inward Flow (millon USO) & 2,005 & 2,632 & 4,430 \\
\hline FDI Stock (milition USO) & 11,118 & 13,750 & 18,180 \\
\hline Number of Greenfield Investments "." & 21 & 35 & 28 \\
\hline FDI Inwards (in \% of GFCerew) & 12.9 & 15.5 & 25.1 \\
\hline FDI Stock (in $\mathrm{S}$ of GDP) & 16.2 & 18.7 & 24.5 \\
\hline
\end{tabular}

Source: UNCTAD - 2014

Azerbaijan's oil resources have reduced the economic problems of the country, so that record highest economic growth in the world during 2006 and 2007 have been won by the country. Azerbaijan's energy reserves are shown in the table below:

GDP in Azerbaijan in 2007 was $\$ 72.2$ billion and economic growth was 31 percent and in 2014, its GDP is 124 billion dollars and its economic growth is $23 \%$. Industry $64 \%$, service 2939 and agriculture $6 \%$ of GDP. Highest percent of labor force is in service sector and least in industry. Inflation rate has risen recently and was 16 percent in 2007. Increased energy price is the major cause of inflation. Cotton, grain, rice, grapes, fruits, vegetables and spices, tea, tobacco and livestock make up the agricultural production and industrial production in Azerbaijan consists of oil and natural gas, petroleum products, steel, iron ore, cement, chemicals and petrochemicals and textiles. Oil production in Azerbaijan in the year 2007 was 934700 barrels/day, of which 795600 were exported. Oil reserves of the country is 7 billion barrels (Mostafapour, 2009: 54-55).

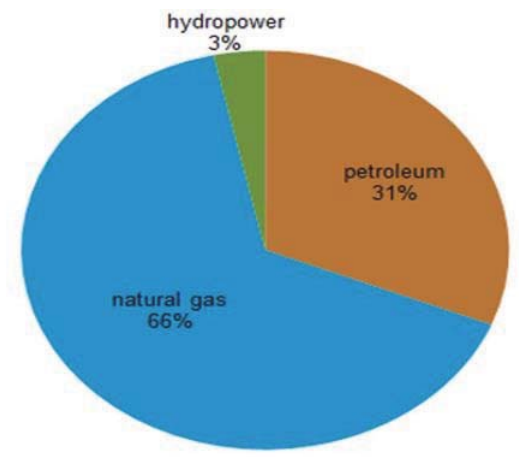

Azerbaijan's Primary Energy Consumptions-2014

Source: international energy statistics database (2014)

The fact that Azerbaijan has been able to broadly maintain its share in global Non-hydrocarbon exports also suggests that competitiveness is balanced. The authorities agreed with this assessment and stressed that improving competitiveness is a top policy priority. They saw public spending on infrastructure as critical to easing physical constraints on the business climate and improving the productivity of private investment.

\section{Capacity for economic cooperation between Iran and Azerbaijan}

Azerbaijan after independence faced many political and economic problems, but gradually, relying on rich mineral resources and their potential capacity, with implementation of reforms, they performed economic situation change so that 
economic growth over the last year topped the countries of the region and the world and increased investment in oil and gas industry and expanding production capacity. (Ghorbanpoor, 2010, 69-75). With the launch of the Baku - TbilisiCeyhan oil pipeline ${ }^{5}$, oil export development played a significant role in the economic growth in Azerbaijan in 2005 and 2006.

According to official statistics of the Republic of Azerbaijan, the country's gross domestic product has been the highest growth in the region since 2005 , and reached 34.5 percent in 2006. But after then, it gradually decreased, so that in 2007 and 2008 it was respectively 25 and 16\%. However, in accordance with the International Monetary Fund, 23.4 and 11.6 in 2007 and 2008. Recently, economic growth in 2014 was announced 23\% by the Ministry of Finance of Azerbaijan (Azerbaijan Trade indicators, 2014).

Relations between Iran and Azerbaijan in recent years has been a lot of ups and downs. Interest of Republic of Azerbaijan to expand cooperation particularly in the fields of construction, transport, energy and industries in which Iran has considerable potential is high. Overall economic cooperation between the two countries is diverse.

If you remove the intersubjective Hobbesian relations, conditions for the expansion of relation two countries in various economic field are in place, the most important ones are mentioned below:

\subsection{Business Cooperation}

Azerbaijan's foreign trade volume in 2008 amounted to 55 billion dollars, which is approximately 72 percent of developed countries. Trade balance in 2008 was nearly 40 billion (Azerbaijan in figures). Italy is the first trade partner of Azerbaijan in 2009. The volume of trade exchange between Iran and Azerbaijan in 2008 totaled 700 million dollars, and had 7.5\% growth compared with last year when it was 650 million dollar (Alipour, 2009: 49). The Iranian imports from Azerbaijan include aluminum and aluminum oxide, non-ferrous pipes and profiles, arms, power transmission, heavy milling machine and gas. Food, fruits, building materials, eggs, detergent, clothes, chocolate, plastic products, ceramic tiles and petroleum products are among the items exported from Iran to Azerbaijan.

\subsection{Benefit from the special position in transportation}

Azerbaijan has no sea and old routes of the Caspian Sea through the Volga-Don Canal ${ }^{6}$ and the Volga - Baltic - Black Sea are unable to meet the growing needs of transport in the country in the process of economic development and trade, and it has to use the communication path of Iran and they could provide a lot of productivity to economic growth of Azerbaijan.

Establishing and strengthening, particularly through land routes to Azerbaijan the development of the north-south on the agenda of Iran, Russia and Azerbaijan in the world. This path is regional in scope, more than one-fifth of the world's population are covered by it and according to the volume of trade in the region, and it brings considerable revenues for the countries located in the path. Currently, 14 countries are in this path. In the future, the connection of Islamic Republic of Iran's Astara railway to Azerbaijan and Rasht-Anzali-Astara railway line completion will provide necessary conditions for the development of north-south route.

Launching this route will increase capacity of communication to 20 million tons above. Business development and an annual traffic of more than 50 thousand trucks and buses and other vehicles between the two countries requires developed road network. In addition north-south transport route, Iran and Azerbaijan are cooperating in other projects such as the international transport TRASICA and ALTID and are and are at intersection of the East-West and NorthSouth.

\subsection{Cooperation in energy transferring}

Azerbaijan has a long history in the production and export of oil and the first oil well was drilled in 1848 in Baku. According to figures published in the International Journal of Oil and Gas (January 2009), oil reserves of 7 billion barrels and gas reserves of 30 trillion cubic feet is estimated, but proven reserves are 1.2 barrels of crude oil and 4.4 trillion cubic feet of gas. Azerbaijan produced 5.44 billion barrels of oil (Shana, 2009). Now it exports over $50 \%$ of its oil production.

\footnotetext{
${ }^{5}$ The Baku-Tbilisi-Ceyhan (BTC) oil pipeline, inaugurated on July 13th, 2006, transports crude oil from Azerbaijan to the European markets. The daily throughput capacity of the pipeline can be as high as 1.2 million barrels of oil.

${ }^{6}$ Lenin Volga-Don Shipping Canal is a canal which connects the Volga River and the Don River at their closest points. Opened in 1952, the length of the waterway is $101 \mathrm{~km}$ (63 mi) $45 \mathrm{~km}$ (28 mi) through rivers and reservoirs). 
Baku - Novorossiysk oil pipeline (the North path) and Baku-Suspa (western path) could not be meet the development of Azerbaijan's oil exports, the Baku - Tbilisi-Ceyhan pipeline with a capacity of one million barrels per day is a major contribution to the country 's oil exports. However, establishment of the other routes can allow export of oil and gas to other parts of the world and increase its bargaining power in global markets.

Problems of exporting Russian gas to Ukraine and Europe in recent years has led European countries to transport gas from Central Asia and the Caspian Sea and seeking new avenues such as Nabucco. Upon Nabucco project ${ }^{7}$ becoming operational, only 5 percent of Europe's gas is supplied. Currently 25 percent of the gas of Europe is supplied by Russia (The world economy, 2009).

It is obvious that countries such as Azerbaijan and Turkey can take full advantage of the pipeline subject to the cooperation of Iran. But Russia insists on using traditional pipeline routes and an increase in the price of gas from Central Asia and the Caucasus to prevent exporters turning to new routes. Asian Land Transport Infrastructure Development project (ALTID) was first introduced in forty and eighth session (1992) of Economic and Social Commission for Asia Pacific. The project is a framework for harmonization of a transport network for the region with a focus on three factors: 1.Asian highway network; 2. Asian railway network; and 3-facilitated transport road network.

TRASICA program was launched in May 1993 in Brussels, during which an East-West shipping route through the Black Sea - Caucasus - Caspian and Central Asian republics, between Europe and Central Asia was decided. Nabucco aims to transport Caspian and Central Asian energy to Europe. The position of the Islamic Republic of Iran in terms of oil and gas resources and its being located in the path of power transmission creates the possibility to play a constructive role in the future of energy supplies in exporting countries such as Azerbaijan as well as energy consuming countries.

Therefore, with the development of domestic production capacity, it should play role in the development of fields in the region and creating new transit paths. Islamic Republic of Iran is to fulfill the objectives of the 20-year strategic document development prospects, strengthening of the network of oil and gas projects are on the agenda. At present, the development of infrastructure for the transportation of energy resources from the Caucasus and Central Asia through Turkey is to be given priority. It is because due to the increase in production capacity and limitations of existing transmission network in the region, the use of the country is inevitable.

Southern and eastern routes are of the comparative advantage that countries tend to use them to transfer resources to countries in East and South-East Asia. The following diagram shows energy supply and demand in Azerbaijan.

\subsection{Cooperation in the exploitation of energy resources}

Azerbaijan after independence pursuing community development programs and investment in the oil and gas sector increased its GDP. For this reason, the country's oil and gas production account for high percentage of its GDP8.

Iran's participation in energy generation and transmission projects in the region, particularly Azerbaijan can also benefit from profit sharing in determining the new direction of energy transfer in the future. 19 oil consortia that operate in the Republic of Azerbaijan, and Islamic Republic of Iran participated in the field of Shah Deniz only and has $10 \%$ of it.

To implement the second phase of development of Shah Deniz gas field, Azerbaijan needs 16 to 20 billion dollars. Azerbaijan's energy resources are shown in the following figure.

\subsection{Iran: Bridge of Azerbaijan and Nakhichevan}

In the past, the relationship between the Republic of Azerbaijan and the Nakhichevan was possible through autonomous Republic of Armenia, but due to political problems and conflicts in these two countries, the Islamic Republic of Iran is now secure way of communication of Nakhichevan and Republic of Azerbaijan. In addition to its role in supplying oil and gas and electricity of Nakhichevan, Iran is a good land bridge to the Republic of Azerbaijan and the isolated Nakhichevan. Without a doubt, the role of our country in recent years has affected the continued dominance of the rule of Republic of Azerbaijan over Nakhichevan.

\footnotetext{
7 The Nabucco-West pipeline (also referred to as the Turkey-Austria gas pipeline) is a proposed natural gas pipeline from the TurkishBulgarian border to Austria. It is a modification of the original Nabucco Pipeline project, which was to run from Erzurum in Turkey to Baumgarten an der March in Austria. The aim of the Nabucco pipeline is to diversify the natural gas suppliers and delivery routes for Europe, thus reducing European dependence on Russian energy.

${ }^{8}$ Despite low prices, oil production in the first half of the year rose by $1.3 \%$, reversing a $3.9 \%$ contraction in January-June 2014 , but is expected to level off for the rest of the year to allow annual maintenance, while fiscal policy is expected to remain somewhat expansionary in 2015 to support the economy.
} 
Cooperation in the field of agriculture in Nakhichevan and use of empty production capacity of conversion industries in West Azerbaijan province, small dam construction, transport and tourism are among other areas of cooperation.

\subsection{The Caspian Sea and the capacity of the political - economic cooperation}

With area of 370 thousand square kilometers, the Caspian Sea is the largest lake in the world shared between the five countries of Iran, Azerbaijan, Russia, Kazakhstan and Turkmenistan and as a transport route, source of food and energy, it has always attracted the attention of local residents.

The region's oil reserves amount to 68 billion cubic meters and $90 \%$ of it is located between the borders of the territory of Azerbaijan and Kazakhstan, and after the Middle East, it is the second largest source of energy (Alipour, 2009). Based on forecast information center of US Energy, oil production in the Caspian Sea reaches 4 million and 300 thousand barrels per day by 2015. After the collapse of the Soviet Union, differences of opinion of littoral states caused agreement in principle to determine the legal regime of the Caspian Sea to face difficultly and some of the countries that had close positions reached bilateral and trilateral agreements (Akiner, 2004: 90-91).

For example, the agreement of the Republic of Azerbaijan with Russia in September 2002 and with Kazakhstan in November 2001 and May 2003. It is obvious that the interests of coastal states depends on a stable and non-stress zone as the basis for cooperation in economic field and coastal countries cannot succeed without close cooperation. For this reason, detente and the development of cooperation with the countries are the fundamental principles of the foreign policy of the Islamic Republic of Iran in the region. With regard to investments and increased production of oil and gas is expected in the next two decades, the Caspian region production and supply of oil and gas is of particular importance after the Persian Gulf.

Due to the geographic and climatic conditions of our country and possibility of taking advantage of the warm southern export terminals in all seasons of the year, it is expected in the future that a considerable amount of energy transmission are will be won by Islamic Republic of Iran and the fulfillment of this would be increase our bargaining power in OPEC.

\subsection{Cooperation in regional and international organizations}

Islamic Republic of Iran and Azerbaijan are members of many international and regional organizations. Two countries are members of the Organization of Islamic Conference and the Economic Cooperation Organization (ECO).

Table (3): 7-periodic changes in total foreign trade of merchandise of OECD countries within the period 1994-2012

\begin{tabular}{|c|c|c|c|c|c|c|c|c|}
\hline \multirow{2}{*}{ Country } & \multicolumn{5}{|c|}{ Total Foreign Trade (Alln US\$) } & \multicolumn{3}{|c|}{$\begin{array}{l}\text { Average annual growth } \\
\text { rate }(\%)\end{array}$} \\
\hline & 1994 & 2000 & 2005 & 2010 & 2012 & $\begin{array}{l}1994- \\
2000 \\
\end{array}$ & $\begin{array}{l}2000- \\
2010 \\
\end{array}$ & $\begin{array}{r}1994 \\
2012 \\
\end{array}$ \\
\hline Afghanistan & 496 & 1,313 & 2,855 & 5,542 & 5,870 & 17.6 & 15.5 & 14.7 \\
\hline Azerbaijan & 1,433 & 2,917 & 11,999 & 33,222 & 43,051 & 12.6 & 27.5 & 20.8 \\
\hline Iran & 33,208 & 42,637 & 96,293 & 166,720 & 161,092 & 43 & 14.6 & 92 \\
\hline Kazakhstan & 6,792 & 13,852 & 45,202 & 91,078 & 136,825 & 12.6 & 207 & 182 \\
\hline Kyrgyz Republic & 656 & 1,059 & 1,774 & 4,983 & 7,268 & 8.3 & 16.8 & 14.3 \\
\hline Pakistan & 16,331 & 19,892 & 41,408 & 59,217 & 68,724 & 3.3 & 11.5 & 8.3 \\
\hline Tajikistan & 1,035 & 1,460 & 2,239 & 3,852 & 5,136 & 5.9 & 10.2 & 9.3 \\
\hline Turkey & 41,376 & 82,278 & 190,250 & 299,427 & 389,014 & 12.1 & 138 & 13.3 \\
\hline Turkmenistan & 3,615 & 4,292 & 7,891 & 12,200 & 26,400 & 29 & 11.0 & 11.7 \\
\hline Uzbekistan & 5,155 & 5,514 & 8,415 & 20,304 & 22,132 & 1.1 & 14.0 & 8.4 \\
\hline ECO Region & 110,097 & 175,214 & 408,326 & 696,625 & 865,513 & 81 & 14.8 & 121 \\
\hline
\end{tabular}

\section{Source: World Trade Organization-2013}

Since the two above said organizations are involved cooperation in the fields of trade, transportation and transit of energy, the two countries can make use of their opportunities to develop their cooperation. ECO member countries are considering the implementation of ECO Trade Agreement and the continued reduction of tariffs and free trade, the implementation of the Framework Agreement and the development of transport transportation, banking and financial 
services through the promotion of ECO Trade and Development Bank and insurance services with the establishment of ECO Reinsurance Company and the expansion of energy transmission lines, which will pave the way for the development of trade and economic growth in the region. ECO region is third in the world in terms of energy production.

\subsection{Cooperation in the creation of new regional arrangements}

The creation of the Caspian littoral countries of the Caspian Sea Economic Cooperation Organization is a project, which if realized, in addition to increasing understanding and economic and political integration of coastal countries, reduces Western countries, especially the US presence and influence in the area. There is a safe and quiet area in favor of economic and political conditions all the countries of the region. 5 littoral states of the Caspian Sea have more than 240 million population. Currently, the Islamic Republic of Iran's trade exchanges with other countries in the Caspian Sea is Over 3 billion dollars (Asadian, 2009: 54-76).

\section{Conclusion}

In total, foreign relations of Azerbaijan with Iran shows that the terms of trade and economic relations was first friendly and Iran was a major economic partner of Azerbaijan, but gradually these relations deteriorated in terms of political and economic terms and faced challenges. Considering the fact that Azerbaijan is a Shiite country and given the geographical proximity and historical and cultural links with the Iranian population, close relations between the two countries is of great ability, while the evidence suggests that these relationships deteriorates over time and is charged with mistrust and suspicion.

In general, according to different conditions and actions such as the law of separation of religion and persecution on charges of espionage and cooperation with Iran, providing greater freedom for the pan Turkism that are opposition forces against Iran and negative advertisements in the state and non-governmental mass media and Azerbaijan against Iran, expanding military cooperation with the United States and improving its relations with Israel despite concerns of Iran, as well as relations between Iran and Armenia are all factors that have led to a cooling of relations between Iran and Azerbaijan.

So in general, we conclude that despite the many convergence characteristics such as shared religion and shared history and culture, there is potential for cooperation in relations between the two countries, and despite the efforts to develop political, economic and security relations, different factors have caused the two countries not to be able to use the existing capacities for cooperation and mutual relations have remained cold.

In the field of economic relations, the years 1993 to 1995 were the golden era of bilateral relations and trade of the Republic of Azerbaijan and Iran as its first partner. But since 1995, under the influence of West-oriented policies and the expulsion of Iran from the oil consortium of Azerbaijan and other identity factors mentioned under the heading of negative political relations, the change in the economic relations between the two countries came into existence (transition from Lockean to Hobbesian condition) and Iran's position among the trade partners of Azerbaijan fell from first to eighth. In the event of removal intersubjective Hobbesian and security relations, there would be much economic capacity in the field of commercial activity, enjoying special status in transport, cooperation in the energy transmission, participation in the exploitation of energy resources, cooperation in the framework of regional organizations and international and regional cooperation in the development of new arrangements between the two countries

\section{References}

Adeebfar, Tamine, (2006), Azerbayjan's Geopolitical Challenge: Improving relations with Iran, Middle East Economic Survey, Vol. 49, No. 49. 04, December 2006.

Akiner, Shirin, (2004), The Caspian: Politics, Energy and Security, (Oxford, Routledge Curzon, 2004), pp. 90-91.

Bourtman, Ilya, (2006). "Israel and Azerbaijan's Furtive Embrace", Middle East Quarterly, Vol. 13, No. 3, Summer 2006.

Central Bank of the Republic of Azerbaijan, 2014, Statistical Bulletin. No. 3 (133), Baku 3/2014.

Efegil, E., and Stone, L. A. (2001). Iran's interests in Central Asia: a contemporary assessment. Central Asian Survey 20, $353-365$.

Ghorbanpoor, Mahmood (2010), Regional Position of Iran in Foreign Trade with Republic of Azerbaijan, World Applied Sciences Journal 9 (1): 69-75.

Golmohammadi, Vali; Atanejad. H and Naghib Shahrebabaki. E, 2015. Foreign Policy Strategies to-wards Economic Development; Comparative Study of the Republic of Turkey and the Islamic Republic of Iran (2004-2013). Mediterranean Journal of Social Sciences, [S.I.], v. 6, n. 3 S2, p. 711.

Hunter, Shireen, (1993), Azerbayjan: search for identity and new partners, in I. Bremmer and R. Taras, Ed., nation and politics in the 
soviet successor states, Cambridge university press, 1993.

Hürriyet Daily News and Economic Review. 30 September 2010. Nabucco venture sees Iraq as top supplier". Retrieved 11 October 2010.

Ibrahimov, Mahir \& Kurbanov, Erjan, (1994) "Policy Brief: Getting it Wrong in the Caucasus", Middle East Quarterly, Vol. 1, No. 4, December 1994.

Ismailzade, Fariz, (2008) "New Tensions Complicate Relations Between Baku and Tehran", Eurasia Daily Monitor, Vol. 3, No. 62, 30 March 2008.

Koolaee, E., and Hafezian, M. H. (2010). The Islamic Republic of Iran and the South Caucasus Republics. Iranian Studies 43, $391-409$.

Rasizade, A. (2004). Azerbaijan after Heydar Aliev. Nationalities Papers 32, 137-164.

Riaux, G. (2008). The formative years of Azerbaijani nationalism in post-revolutionary Iran. Central Asian Survey 27, 45-58.

Socor, Vladimir (23 May 2012). "'Nabucco-West": Abridged Pipeline Project Officially Submitted to Shah Deniz Consortium". Eurasia Daily Monitor 9 (98) (Heritage Foundation). Retrieved 24 May 2012.

Thomas De Waal,(2003), Black Garden: Armenia and Azerbaijan Through Peace and War, NYU Press, 2003, ISBN 0-8147-1945-7, p. 134.

Tokluoglu, C. (2011). The Political Discourse of the Azerbaijani Elite on the Nagorno-Karabakh Conflict (1991-2009). Europe-Asia Studies 63, 1223-1252.

Tokluoglu, C. (2012). Perceptions of State and Leadership in Post-Soviet Azerbaijan (1991-2009). Middle Eastern Studies 48, 319-343.

Waltz, Kenneth H. (1979), Theory of International Politics, New York: Random House.

Wieclawski, Jacek (January 2011), Contemporary Realism and the Foreign Policy of the Russian Federation, International Journal of Business and Social Science, Vol. 2, No. 1.

Wilhelmsen, J. (2009). Islamism in Azerbaijan: how potent? Studies in Conflict \& Terrorism 32, 726-742.

Yongs, Richard (2009), Energy Security Europes New Foreign Policy Challenge, Routledge, p. 101. 